\title{
Pengaruh Naungan terhadap Pertumbuhan dan Aktivitas Antioksidan pada Bayam Merah (Alternanthera amoena Voss.)
}

\section{The Impact of Shade to the Growth and the Antioxidant Activity of Red Spinach (Alternanthera amoena Voss.)}

\author{
Lutfiyatul Khusni $^{1 *}$, Rini Budi Hastuti ${ }^{2}$, Erma Prihastanti ${ }^{2}$ \\ ${ }^{1}$ Progam Studi Biologi, Departemen Biologi, Fakultas Sains dan Matematika, Universitas Diponegoro \\ ${ }^{2}$ Departemen Biologi, Fakultas Sains dan Matematika, Universitas Diponegoro \\ Jl. Prof. Soedarto, SH, Tembalang, Semarang \\ *Email : lutfikhusnibio@gmail.com
}

Diterima 2 Oktober 2017 / Disetujui 24 Januari 2018

\begin{abstract}
ABSTRAK
Produksi hasil budidaya bayam merah masih belum memenuhi kebutuhan masyarakat. Budidaya bayam merah ini bertujuan untuk memperoleh senyawa antioksidan tinggi,yang dipengaruhi oleh faktor naungan. Naungan berkaitan dengan cahaya yang diterima oleh tanaman dan mempengaruhi proses fotosintesis serta pertumbuhan untuk menghasilkan aktivitas antioksidan. Tujuan penelitian ini yaitu untuk mengetahui pengaruh naungan terhadap pertumbuhan dan menganalisis pengaruh naungan terhadap aktivitas antioksidan yang terdapat pada bayam merah pada tingkat naungan yang berbeda. Rancangan penelitian ini menggunakan RAL satu faktor yaitu naungan. Analisis data menggunakan ANOVA pada taraf signifikansi $95 \%$ dan jika beda nyata dilanjutkan uji DMRT. Hasil penelitian menunjukkan perlakuan naungan tidak berpengaruh nyata terhadap pertumbuhan tetapi cenderung menurunkan pertumbuhan bayam merah, namun perlakuan naungan menunjukkan adanya pengaruh nyata terhadap aktivitas antioksidan bayam merah. Pertumbuhan bayam merah optimal intensitas cahaya kisaran 1965 lux. Perlakuan naungan 70\% merupakan naungan yang paling baik menghasilkan aktivitas antioksidan paling tinggi dibanding perlakuan lain.
\end{abstract}

Kata Kunci : naungan, pertumbuhan, aktivitas antioksidan, bayam merah

\begin{abstract}
Production of red spinach cultivation is still not meet the needs of the community. The growth of red spinach culture to obtain high antioxidant compounds that influenced by shading factor. The shade is related to the light received by plants and affect the process of photosynthesis and growth to produce antioxidant activity. The purpose of this study is to determine the effect of shade on growth and analyze the effect of shade on antioxidant activity contained in red spinach at different shade levels. The design of this study used a single factor RAL ie shade with treatment without shade. Data analysis using ANOVA at 95\% significance level and if real difference continued DMRT test. The results showed that shade treatment had no significant effect on growth but tended to decrease the growth of red spinach, but shade treatment showed significant effect on red spinach antioxidant activity. The growth of red spinach optimum light intensity range 1965 lux. The shade treatment of $70 \%$ is the best shade to produce the highest antioxidant activity compared to other treatments.
\end{abstract}

Keywords: shade, growth, antioxidant activity, red spinach

\section{PENDAHULUAN}

Bayam merah (Alternanthera amoena Voss.) merupakan sayuran yang memiliki nilai ekonomis yang tinggi dibandingkan dengan beberapa jenis bayam yang lainnya (Rukmana,
2008). Bayam merah semula dikenal sebagai tanaman hias, namun dalam perkembangan selanjutnya bayam merah difungsikan sebagai bahan pangan sumber protein, vitamin $\mathrm{A}$ dan $\mathrm{C}$ sedikit vitamin $\mathrm{B}$, mengandung garam-garam mineral dan pigmen antosianin (Sunarjono, 2006; 
Astawan, 2004). Antosianin termasuk senyawa fenolik yang masuk kelompok flavonoid dan berfungsi sebagai antioksidan (Damanhuri, 2005). Namun hasil produksi budidaya bayam merah masih belum memenuhi kebutuhan masyarakat sehingga pada tahun 2008 Indonesia masih mengimpor sekitar 57.801 ton (Wijaya, 2006).

Cahaya memegang peranan penting dalam proses fisiologis tanaman, terutama fotosintesis, respirasi dan transpirasi. Fotosintesis sebagai sumber energi bagi reaksi cahaya dan fotolisis air menghasilkan ATP dan $\mathrm{NADPH}_{2}$. Intensitas cahaya yang tinggi menyebabkan laju fotosintesis tanaman maksimum (Noviyanti, 2005). Cahaya mempengaruhi laju transpirasi tanaman. Intensitas cahaya yang meningkat menyebabkan transpirasinya juga meningkat karena banyak stomata yang terbuka. Peningkatan intensitas cahaya menyebabkan peningkatan laju respirasi. Sinar akan mempercepat proses fotosintesi kemudian fotosintesis akan menambah substrat, sedangkan penambahan substrat akan mempercepat proses laju respirasi (David dan Anne, 2013).

Naungan merupakan salah satu cara yang dapat digunakan untuk membedakan intensitas cahaya yang diterima oleh tanaman di bawahnya. Pembuatan naungan dapat dilakukan dengan menggunakan paranet. (Nagasubramaniam et al., 2007). Salah satu faktor luar penting yang dapat mempengaruhi pertumbuhan dan produksi suatu tanaman adalah intensitas cahaya. Sinar matahari memberikan pengaruh terhadap pertumbuhan tanaman, seperti menyediakan sumber energi untuk fotosintesis. Hal tersebut menyebabkan kandungan karbohidrat akan berkurang pada intensitas cahaya rendah atau gelap (Yuliarti, 2010).

Perlakuan naungan menjadi salah satu faktor abiotik yang menyebabkan kondisi stres pada tanaman. Kondisi stres pada tanaman disebabkan oleh akumulasi Reaktif Oksidatif Spesies (ROS) yang dapat mempengaruhi produksi antioksidan yang dihasilkan tanaman. Deepak et al., (2015) menyatakan tanaman memiliki kemampuan bawaan untuk mensintesis antioksidan nonenzimatik. Kondisi stres dari pengaruh biotik dan abiotik mengakibatkan produksi Reaktif Oksigen
Spesies (ROS) meningkat pada tanaman sehingga menyebabkan induksi stres oksidatif. Respon tanaman terhadap peningkatan stres oksidatif mengakibatkan tanaman menambah produksi dan akumulasi beberapa antioksidan.

Antioksidan juga merupakan senyawa yang dapat menghambat reaksi oksidasi dengan mengikat radikal bebas dan molekul yang sangat reaktif, sehingga kerusakan sel dapat dihambat (Winarsi, 2007). Antioksidan alami merupakan jenis antioksidan yang berasal dari tumbuhan dan hewan, umumnya mempunyai gugus hidroksi dalam struktur molekulnya. Antioksidan pada tanaman yang sering diteliti umumnya berasal dari golongan senyawa fenolik (Ikhlas, 2013). Aktivitas antioksidan dapat ditentukan secara invitro dengan beberapa metode, salah satunya dengan menggunakan metode 2,2-difenil-1pikrilhidrazil (DPPH). DPPH merupakan radikal bebas yang stabil pada suhu kamar dan sering digunakan untuk menilai aktivitas antioksidan beberapa senyawa atau ekstrak bahan alam (Erawati, 2012).

Penelitian sebelummya mengenai pemberian naungan pada tanaman cabai merah (Capsicum annuиm L.) berpengaruh dari aspek morfologis Khoiri (2010). Pemberian naungan tidak berpengaruh secara nyata terhadap tinggi, berat kering tanaman, lebar daun, jumlah daun dan panjang daun dibandingkan dengan perlakuan kontrol. Berdasarkan latar belakang tersebut perlu dilakukan penelitian untuk mengetahui pengaruh naungan terhadap pertumbuhan dan aktivitas antioksidan pada tanaman bayam merah.

\section{METODE PENELITIAN}

Penelitian dilaksanakan di dilaksanakan Kebun Percobaan Departemen Biologi, Fakultas Sains dan Matematika Universitas Diponegoro. Waktu pelaksanakan pada bulan Mei sampai dengan Juni 2017. Percobaan menggunakan rancangan acak lengap (RAL) secara faktorial dengan 4 ulangan untuk pertumbuhan dan 3 ulangan untuk uji aktivitas antioksidan. Adapun Faktor perlakuan P0 (tanpa naungan) P1 (naungan $50 \%$ ), dan P2 (naungan 70\%). Dengan demikian ada 3 perlakuan dan 4 ulangan untuk pertumbuhan 
dan 3 ulangan untuk uji aktivitas antioksidan. Data yang diperoleh dianalisis menggunakan ANOVA pada taraf signifikansi $95 \%$ dan jika beda nyata dilanjutkan uji Duncan Multiple Range Test (DMRT).

Alat yang digunakan antara lain: polybag, kamera, timbangan digital, microtube, sentrifuse, paranet, lux meter, erlenmeyer $250 \mathrm{ml}$, gelas ukur, erlenmeyer, alumunium foil, stirer, mortar, alu, oven, dan spektrofotometer UV-Vis.

Bahan yang digunakan antara lain: tanah, pupuk kandang, sekam, serta benih tanaman bayam merah yang diperoleh dari toko pertanian, serbuk DPPH (2,2 -difenill-1- pikrilhidrazil), etanol, metanol, serta aquades.

Pelaksaan penelitian diawali dengan penanaman bayam merah sebulan dengan perlakuan tanpa naungan, naungan $50 \%$ dan naungan $70 \%$. Pemanenan dilakukan setelah 1 bulan dengan menghitung tinggi tanaman, jumlah daun, panjang akar, berat basah, berat kering dan uji aktivitas antioksidan. Perhitungan aktivitas antioksidan tanaman bayam merah dengan cara mengambil daun bayam merah masing-masing perlakuan, dicuci bersih dimasukkan di dalam oven pada suhu $30^{\circ} \mathrm{C}$ selama 1 jam. Sebanyak 0,1 gram daun bayam merah kemudian ditumbuk dan dimasukkan kedalam microtube. Etanol sebanyak $1 \mathrm{ml}$ ditambahkan kedalam microtube lalu dimasukkan dalam sentrifuge dan putar selama 5 menit pada kecepatan 6000 rpm dan biarkan selama 5 menit agar mengendap sempurna. Tahapan selanjutnya pembuatan larutan DPPH sebagai kit antioksidan yaitu $2 \mathrm{mg}$ DPPH ditimbang kemudian ditambah $1 \mathrm{ml}$ metanol, lalu stir dengan menggunakan stirer secara perlahan selama 2 menit. Tahap selanjutnya sampel yang akan dihitung antioksidannya dilarutkan dalam larutan $5 \mathrm{mg}$ DPPH yang mengandung metanol. Masing-masing sampel diukur absorbansinya pada $\lambda$ optimal $517 \mathrm{~nm}$. Data hasil absorbansi masingmasing sampel digunakan untuk mencari \% inhibisinya. Rumus untuk mencari \% inhibisi menurut Bintang (2010) adalah sebagai berikut:

\section{$\%$ Inhibisi $=$ Absorban kontrol - Absorban sampel $\times 100 \%$ Absorban Kontrol}

\section{Keterangan:}

Absorban Kontrol = Absorbansi pada DPPH tanpa sampel

Absorbansi Sampel = Absorbansi pada DPPH setelah ditambah sampel

\section{HASIL DAN PEMBAHASAN}

\section{Tinggi Tanaman}

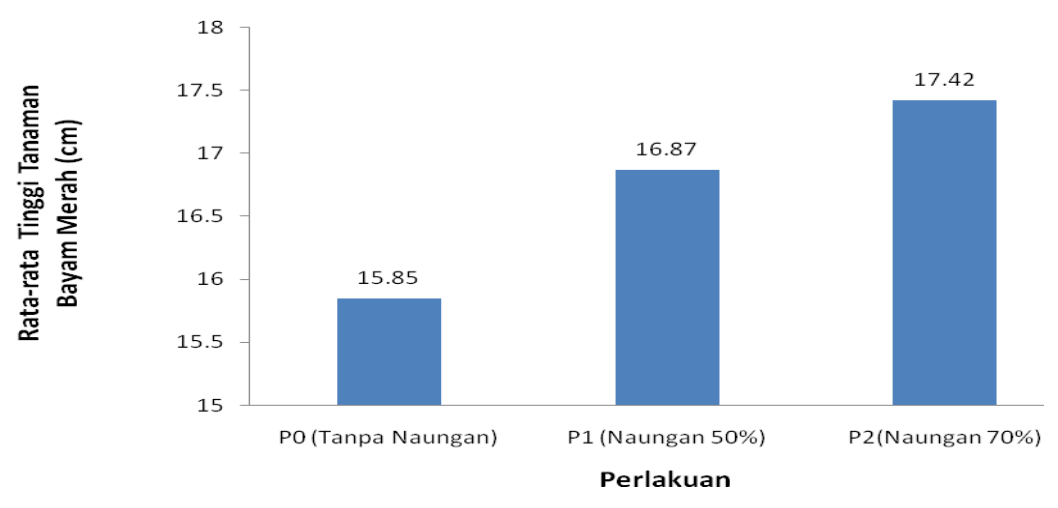

Gambar 1.Histogram rerata tinggi tanaman bayam merah (Alternanthera amoena Voss.) (cm) setelah pemberian tingkat naungan yang berbeda-beda.

Hasil uji ANOVA pada taraf signifikan 95\% menunjukkan tidak berpengaruh nyata.
Berdasarkan hasil pengamatan tinggi tanaman dengan perlakuan P2 atau naungan $70 \%$ 
menunjukkan tinggi tanaman paling tinggi daripada perlakuan naungan $50 \%$ (P1) dan tanpa naungan (P0). Hal ini disebabkan karena pada tanaman dengan perlakuan naungan $70 \%$ cahaya matahari yang diterima lebih sedikit sehingga tanaman menjadi lebih tinggi. Menurut Maria
(2009), menyatakan bahwa tanaman yang terkena naungan akan mengalami pemanjangan terutama sel-sel pada batang. Intensitas cahaya rendah yang menghasilkan kadar auksin yang meningkat pada meristem apikal yang merangsang pemanjangan sel tanaman.

\section{Jumlah Daun}

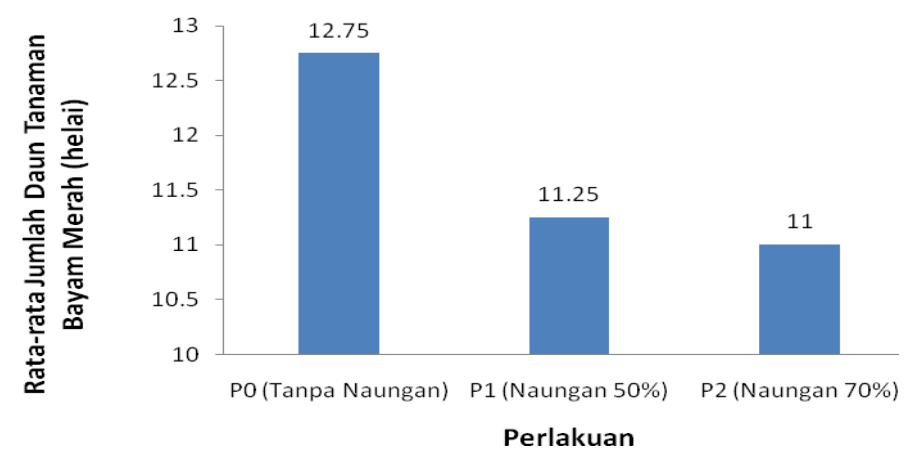

Gambar 2. Histogram rerata jumlah daun tanaman bayam merah (helai) setelah perlakuan tingkat naungan yang berbeda-beda

Hasil uji ANOVA pada taraf signifikan 95\% menunjukkan tidak berbeda nyata. Berdasarkan hasil pengamatan jumlah daun tanaman paling banyak pada perlakuan P0 (tanpa naungan) dibandingkan perlakuan P1 (naungan 50\%) dan perlakuan P2 (naungan 70\%). Hal ini disebabkan karena tanaman bayam merah pada perlakuan tanpa naungan mendapatkan sinar matahari yang cukup, sehingga dapat melakukan proses metabolisme dan pertumbuhan yang baik jika dibandingkan dengan perlakuan yang lain. Marjenah (2001) menyatakan bahwa jumlah daun menjadi penentu utama kecepatan pertumbuhan. Bramantyo dkk, (2013) mengungkakapkan apabila respon tanaman terhadap naungan dicirikan oleh pertumbuhan daunnya. Ukuran daun akan semakin meningkat dengan menurunnya intensitas cahaya akibat perlakuan taraf naungan yang semakin meningkat. Kondisi daun yang berada dalam kondisi ternaungi akan mengalami penuaan yang lebih cepat dan akibatnya daun tidak menyumbang fotosintat bersih sehingga laju pertumbuhan vegetatif terhambat dan jumlah daun pada tanaman menjadi berkurang .

\section{Panjang Akar}

Hasil uji ANOVA pada taraf signifikan 95\% menunjukkan tidak berbeda nyata Berdasarkan hasil pengamatan panjang akar yang diperoleh, tanaman dengan perlakuan P0 (tanpa naungan) menunjukkan panjang akar tanaman paling tinggi dibanding perlakuan P1 (naungan 50\%) dan perlakuan P2 (naungan 70\%). Hal ini disebabkan karena tanaman bayam merah pada perlakuan tanpa naungan mendapatkan sinar matahari yang cukup, sehingga dapat melakukan proses metabolisme dan pertumbuhan yang baik jika dibandingkan dengan perlakuan yang lain. Pantilu dkk, (2012) menyatakan bahwa pertumbuhan panjang akar pada tanaman bayam merah membutuhkan intensitas cahaya tinggi, sehingga tanpa naungan paling baik untuk pertumbuhan panjang akar bayam merah. Kondisi ini menunjukkan bahwa cahaya berperan penting dalam proses fisiologi tanaman, terutama fotosintesis, respirasi, dan transpirasi 


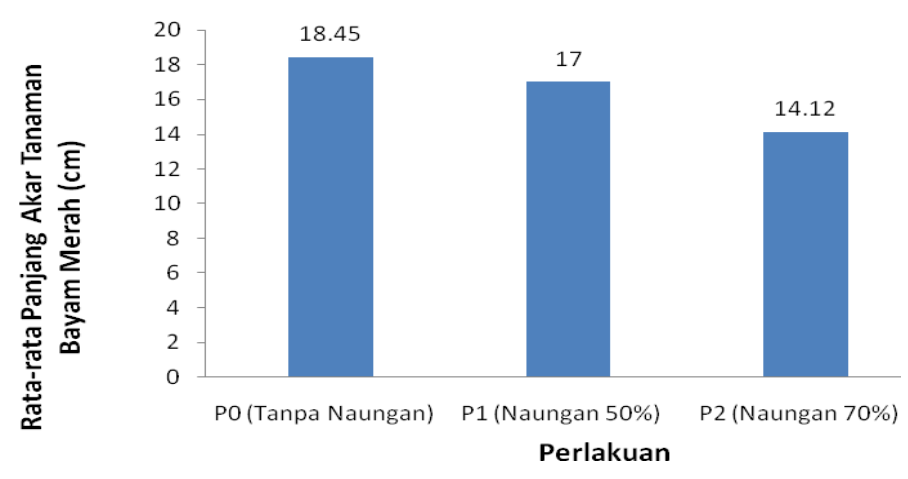

Gambar 3. Histogram rerata panjang akar tanaman bayam merah $(\mathrm{cm})$ setelah perlakuan tingkat naungan yang berbeda-beda.

\section{Berat Basah Tanaman}

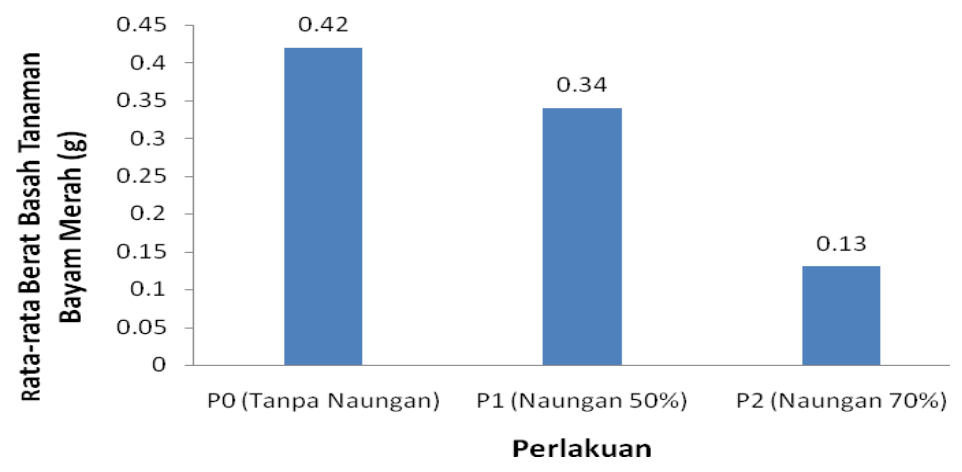

Gambar 4. Histogram rerata berat basah tanaman bayam merah $(\mathrm{g})$ setelah perlakuan tingkat naungan yang berbeda-beda.

Hasil uji ANOVA pada taraf signifikan 95\% menunjukkan tidak berpengaruh nyata. Berdasarkan hasil pengamatan berat basah yang diperoleh, tanaman dengan perlakuan P0 (tanpa naungan) menunjukkan berat basah paling tinggi dibanding perlakuan naungan $50 \%$ (P1) dan naungan $70 \%(\mathrm{P} 2)$. Hal ini menunjukkan bahwa metabolisme tanaman tanpa naungan berjalan dengan sangat baik. Berat basah tanaman merupakan berat tanaman pada saat tanaman masih hidup dan ditimbang secara langsung setelah panen, sebelum tanaman layu akibat kehilangan air. Zulfita (2012) menyatakan bahwa tanaman dengan aplikasi naungan kurang mendapatkan intensitas cahaya matahari sehingga proses fotosintesis tidak lebih optimum dibandingkan dengan tanaman tanpa naungan. Kondisi ini dikarenakan dalam pertumbuhan berat basah tanaman bayam merah membutuhkan bantuan proses fotosintesis yang baik sehingga intensitas cahaya yang tinggi sangat diperlukan. Pantilu dkk, (2012) menyatakan perlakuan naungan dapat mengakumulasi produk fotosintat pada tingkat cahaya yang dibutuhkan dalam proses fotosistesis pada tanaman. Akumulasi fotosintat dapat berupa karbohidrat atau senyawa organik lainnya. Karbohidrat dapat diubah menjadi protein, lemak, vitamin, atau senyawa yang lain.

\section{Berat Kering Tanaman}

Hasil uji ANOVA pada taraf signifikan 95\% menunjukkan tidak berpengaruh nyata. Berdasarkan hasil pengamatan berat kering yang diperoleh tanaman dengan perlakuan P0 (tanpa naungan) menunjukkan berat kering tanaman paling tinggi dibanding perlakuan naungan $50 \%$ 
(P1) dan naungan 70\% (P2). Hal ini disebabkan karena tanaman tanpa naungan melakukan metabolisme fotosintesis yang optimal sehingga menghasilkan asimilat yang tinggi. Menurut Lakitan (2007) berat kering tanaman mencerminkan akumulasi senyawa organik yang berhasil disintesis tanaman dari senyawa anorganik, terutama air dan karbondiosida. Berat kering tanaman merupakan akibat efisiensi penyerapan dan pemanfaatan radiasi matahari yang tersedia, sepanjang musim pertumbuhan oleh tajuk tanaman. Pantilu dkk, (2012) menyatakan naungan menyebabkan titik kompensasi cahaya sangat rendah dan menyebabkan pertumbuhannya sangat lambat karena berkaitan erat dengan proses fotosintesis, respirasi dan proses-proses metabolisme saat pertumbuhannya.

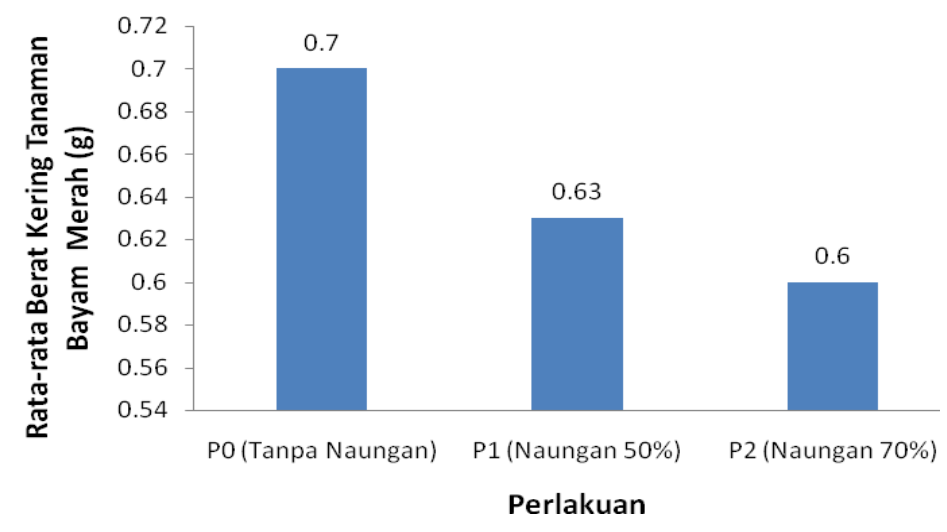

Gambar 5. Histogram rerata berat kering tanaman bayam merah (g) setelah perlakuan tingkat naungan yang berbeda-beda.

\section{Aktivitas Antioksidan Bayam Merah}

Hasil uji ANOVA pada taraf signifikan 95\% yang dilanjutkan dengan uji lanjut Duncan pada taraf signifikasi 95\% menunjukkan ada perbedaaan nyata perlakuan dalam naungan meningkatkan aktivitas antioksidan. Berdasarkan Tabel 1 dapat diketahui bahwa pada perlakuan tingkat naungan yang berbeda memiliki aktivitas antioksidan yang berbeda nyata yang ditunjukkan dengan nilai $\%$ inhibisinya. Perlakuan P2 (naungan 70\%) memiliki aktivitas antioksidan yang paling tinggi. Hal ini menunjukkan bahwa perlakuan P2 memiliki kandungan senyawa antioksidan seperti klorofil, dan vitamin $\mathrm{C}$ yang lebih banyak dibandingkan antosianinnya. Daun tanaman ternaungi lebih tipis dibanding tanaman tanpa naungan. Pigmen yang dihasilkan tanaman ternaung justru lebih tinggi karena memiliki memiliki grana yang lebih banyak. Muhuria (2006) menyatakan bahwa daun yang ternaungi memiliki lebih banyak grana pervolume kloroplas, kloroplas lebih besar, dan menghasilkan pigmen tanaman seperti klorofil yang lebih besar daripada daun yang berkembang pada kondisi cahaya matahari penuh.

Warna daun pada perlakuan ternaung baik naungan $50 \%$ dan $70 \%$ cenderung berwarna kehijauan. Warna pigmen yang dihasilkan pada daun ternaung menunjukkan adanya klorofil yang terbentuk selain antosianin. Kondisi naungan diketahui dapat meningkatkan ukuran antena klorofil yang disertai peningkatan sel klorofil sehingga mampu menghasilkan klorofil a dan klorofil $b$ yang lebih tinggi daripada kondisi tanpa naungan. Tanaman ternaungi lebih banyak mengandung klorofil $\mathrm{b}$ karena tiap kloroplas mempunyai lebih banyak grana dibandingkan dengan daun pada tanaman tanpa naungan. Grana yang dihasilkan semakin banyak apabila semakin besar tingkat naungan yang diterima oleh tanaman. Graham et al., (2006) menyatakan bahwa klorofil $\mathrm{b}$ merupakan pigmen asesoris. Korofil $\mathrm{b}$ menyerap cahaya yang berbeda dengan klorofil a. Klorofil $b$ dan meningkatkan penyerapan dari cahaya tampak (visible light) yang berguna untuk fotosintesis. 


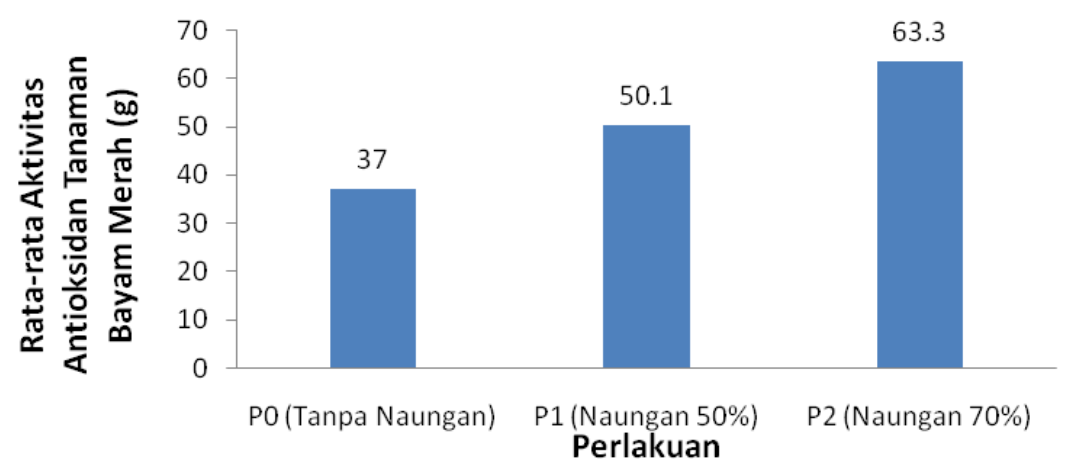

Gambar 6. Histogram rerata aktivitas antioksidan tanaman bayam merah (\%inhibisi) setelah perlakuan tingkat naungan yang berbeda-beda

Kandungan vitamin C (asam askorbat) pada bayam merah juga merupakan senyawa antioksidan. Vitamin $\mathrm{C}$ pada perlakuan naungan $70 \%$ lebih tinggi dibandingkan perlakuan lain. Hal ini disebabkan karena adanya pengaruh cahaya matahari terhadap tanaman bayam merah tersebut. Nasution (2010) menjelaskan bahwa sinar matahari merupakan energi yang sangat penting untuk proses fotosintesis pada tumbuhan hijau daun, dimana kadar air pada tanaman bayam tersebut akan mengalami penguapan sehingga kadar glukosa sebagai bahan baku sintesis akan mempengaruhi berkurangnya kadar vitamin $\mathrm{C}$, dimana air adalah sebagai bahan baku dan media reaksi pada tanaman bayam tersebut. Davey et al,. (2006) menyatakan vitamin C diproduksi oleh tumbuhan dalam jumlah yang besar. Fungsi vitamin $\mathrm{C}$ bagi tumbuhan adalah sebagai agen antioksidan yang berperan dalam pertumbuhan sel, berfungsi seperti hormon, dan ikut berperan dalam proses fotosintesis. Menurut Gordon et al, (2001), asam askorbat merupakan jenis antioksidan yang memiliki mekanisme aktivitas antioksidan yaitu meningkatkan aktivitas antioksidan.

Warna daun pada perlakuan tanpa naungan menghasilkan warna yang merah. Hal ini menandakan bahwa perlakuan tanpa naungan memiliki sedikit klorofil karena warna hijaunya tidak terlihat berkembang sehingga warna merahlah yang mendominasi. Perlakuan tanpa naungan menghasilkan lebih banyak antosianin daripada perlakuan naungan. Antosianin berfungsi melindungi kloroplas terhadap intensitas cahaya yang tinggi sehingga warna merah mendominasi dan menutupi klorofil pada daun perlakuan tanpa naungan. Sesuai pernyataan Salisbury dan Ross (1992) bahwa antosianin merupakan jenis flavonoid yang mengalami peningkatan apabila terkena cahaya secara langsung.

\section{KESIMPULAN}

Perlakuan naungan tidak berpengaruh nyata terhadap pertumbuhan tetapi cenderung menurunkan pertumbuhan bayam merah, namun perlakuan naungan menunjukkan adanya pengaruh nyata terhadap aktivitas antioksidan bayam merah. Pertumbuhan bayam merah optimal intensitas cahaya kisaran 1965 lux. Perlakuan naungan 70\% (P2) merupakan naungan yang paling baik menghasilkan aktivitas antioksidan paling tinggi dibanding perlakuan lain.

\section{DAFTAR PUSTAKA}

Astawan, Made. 2004. Kiat Menjaga Tubuh Tetap Sehat. Tiga Serangkai, Solo.

Bintang, M. 2010. Biokimia Teknik Penelitian. Erlangga, Jakarta.

Bramantyo J, Samanhudi, Rahayu M. 2013. Pengaruh naungan dan cekaman air terhadap pertumbuhan dan hasil purwoceng (Pimpinella pruatan) di Tawangmangu. J Agron Res 2(5): 53-64 
Damanhuri. 2005. Pewarisan Antosianin dan Tanggap Klon Tanaman Ubi Jalar (Ipomea batatas (L.) Lamb) terhadap Lingkungan Tumbuh. Disertasi. Malang: Program Studi Ilmu Pertanian Program Pascasarjana Universitas Brawijaya 1

Davey MW, Kenis K, Keulemans J. 2006. Genetic control of fruit vitamin C contents. Journal Plant Physiology. 142: 343-351

David R. Holding and Anne M. Streich. 2013. Plant Growth Processes: Transpiration, Photosynthesis, and Respiration. Journal University of Nebraska-Lincoln

Deepak M. Kasote, Surendra S. Katyare, Mahabaleshwar V. Hegde, Hanhong Bae. 2015. Significance of Antioxidant Potential of Plants and its Relevance to Therapeutic Applications. J Biol Sci

Erawati. 2012. Uji Aktivitas Antioksidan Ekstrak Daun Garcinia daedalanthera Pierre dengan Metode DPPH (1,1-Difenil Pikrilhidrazil) dan Identifikasi Golongan Senyawa Kimia dari Fraksi Paling Aktif. Skripsi. Program Sarjana Ekstensi Farmasi Fakultas MIPA Universitas Indonesia, Depok.

Gordon MH J. Pokorny, N. Yanishlieve, M. Gordon.2001. Antioksidants in Food. New York : CRC Press.

Graham, L.E., J.E. Graham, L.W. Wilcox. 2006. Plant Biology. Prentice Hall, London.

Ikhlas, N. 2013. Uji Aktivitas Antioksidan Ekstrak Herba Kemangi (Ocimum americanum Linn) dengan Metode DPPH (2,2-Difenil-1Pikrilhidrazil). Skripsi. Fakultas Kedokteran dan Ilmu Kesehatan Program Studi Farmasi UIN Syarif Hidayatullah, Jakarta.

Khoiri, Mustofa. 2010. Pengaruh Naungan terhadap Pertumbuhan dan Laju Fotosintesis Tanaman Cabe Merah (Capsicum annuum L) sebagai Salah Satu Sumber Belajar Biologi. Jurnal Biologi Universitas Muhammadiyah.

Lakitan, B. 2007. Dasar-Dasar Fisiologi Tumbuhan. Raja Grafindo Persada, Jakarta.
Maria, G.M. 2009. Respon Produksi Tanaman Kangkung Darat (Ipomea reptans Poir) Terhadap Variasi Waktu Pemberian Pupuk Kotoran Ayam. Jurnal Ilmu Tanah 7(1) : 18-22.

Marjenah, 2001. Pengaruh Perbedaan Naungan di Persemaian terhadap Pertumbuhan dan Respon Morfologi Dua Jenis Semai Meranti. Jurnal Ilmiah Kehutanan "Rimba Kalimantan" Vol. 6. Nomor. 2. Samarinda, Kalimantan Timur.

Muhuria, L. 2007. Mekanisme fisiologi dan pewarisan sifat toleransi kedelai (Glycine $\max$ L. Merrill) terhadap intensitas cahaya rendah [disertasi]. Bogor: Program Pascasarjana, Institut Pertanian Bogor. $163 h$.

Nagasubramaniam A., G. Pathamanabhan dan V. Mallika. 2007. Studies on improving production potential of baby corn with foliar spray of plant growth regulators. Jurnal Plant Mol. Biol. 21: 154-157.

Nasution, Khairunnisyah. 2010. Pengaruh Cahaya Matahari terhadap Kadar Vitamin C pada Tanaman Bayam dengan Naungan dan Tanpa Naungan. Skripsi Universitas Sumatera Utara.

Noviyanti, Rintis. 2005. Kamus Biologi Bergambar. Erlangga, Jakarta.

Pantilu, L.I., F.R. Mantiri, N. Song Ai, D. Pandiangan. 2012. Respons morfologi dan anatomi kecambah kacang kedelai (Glycine $\max ($ L.) Merill) terhadap intensitas cahaya yang berbeda .Jurnal Bioslogos 2 (2).

Rukmana, Rahmat. 2008. Bayam, Bertanam dan Pengolahan Pascapanen. Kanisius, Yogyakarta.

Salisbury, F.B., dan C.W. Ross. 1995. Fisiologi tumbuhan. Jilid 1 Terjemahan Diah R. Lukman dan Sumaryo. ITB, Bandung.

Sunarjono, H. 2006. Bertanam 30 Jenis Sayur. Penebar Swadaya, Jakarta

Wijaya. 2006. Pengaruh Dosis Pupuk Nitrogen dan Jumlah Benih Perlubang Terhadap Pertumbuhan dan Hasil Tanaman Bayam. 
Jurnal AGRIJATI. Cirebon: Fakultas Pertanian UNSWAGATI.

Winarsi, Hery. 2007. Antioksidan Alami dan Radikal Bebas. Kanisius, Yogyakarta.

Yuliarti, N. 2010. Kultur Jaringan Skala Rumah Tangga. Andi, Yogyakarta.

Zulfita, D. 2012. Kajian fisiologi tanaman lidah buaya dengan pemotongan ujung pelepah pada kondisi cekaman kekeringan. $J$. Perkebunan \& LahanTropika 2 (1). 